\title{
MUSEERNA OCH KUNSKAPSSAMHÄLLET
}

Olof Eriksson

jag är ett steg mot slumpen och fördärvet jag är ett språng i friheten och självet jag är en ingångsskylt till nya paradis

Edith Södergran

Vi stär inför en växande kunskapsmassa och en dramatiskt ökad kapacitet att hantera den. Om detta också innebär en kvalitativ forrändring till en ny sambällsform, ett kunskapssamhälle, är inte lika givet. Olika tolkningar med skilda implikationer för museerna kan tänkas.

Om vi i det sena 1900-talet är på väg in i en ny samhällsordning är svårt att veta. Vi vacklar mellan begreppen informationsoch kunskapssamhälle utan att veta om förändringarna är reella eller om begreppen är skapade som redskap för gruppintressen och maktkamp. För museerna uppstår frågan om de skall förhålla sig som utanförstående och vänta tills vi i historiens ljus vet besked och då berätta. Eller om de är så inflätade i de krafter som skapar det nya samhället (om det nu alls blir av) att de inte kan stå vid sidan om vad som möjligen är en av historiens stora vändpunkter.

\section{JORDBRUKSSAMHÄLLE, INDUSTRISAMHÄLLE, KUNSKAPSSAMHÄLLE}

Ordens rad manar fram föreställningar om samhällsformer som följer varandra som pärlor på ett snöre. I verkligheten är grän- serna oklara. Framväxten av det nya pågår i decennier, kanske århundraden utanför samhällsdebattens ljuskrets. Några egentliga slut kan knappast skönjas. Vad det handlar om är snarare att de olika samhällena lagras på varandra.

Statistiken ger besked om sektorernas bidrag till BNP, till export och handelsbalans osv. och till sysselsättning. OECD definierar industrisamhälle som ett där mer än $20 \%$ av de yrkesverksamma arbetar $\mathrm{i}$ industrin. $\mathrm{Nu}$ vill många se belägg för ett informations- eller kunskapssamhälle i att de som arbetar med information eller hanterar kunskap är fler än de som arbetar i industrin. Gränserna är emellertid flytande. Andra faktorer spelar in.

Den jordägande adeln och bönderna dominerade jordbrukssamhället. Staten fick sina inkomster genom att äga och beskatta jord. Krigsmakten underhölls i fredstid med att knektar i alla grader tilldelades jord osv. Mycket av detta är borta, 
men det är ändå inte givet att jordbrukssamhället gått i graven. Näringarna har eget departement i regeringskansliet och eget utskott i riksdagen, ett eget forskningsråd och ett eget universitet med en professorstäthet som andra bara kan drömma om och därtill ett eget museum i Julita. De kramar ur Sverige och EU 7-8 miljarder $\mathrm{kr}$ i rena driftsbidrag till några tiotal tusen brukningsenheter. Så ser inte ett dödsbo ut.

Industrisamhället började inte när Sverige någon gång i seklets början passerade den officiella OECD-gränsen. Det började långt tidigare, $\mathrm{i}$ ett protoindustriellt skede som sakta vävdes samman med framväxande vetenskap under 1700- och 1800 talen till en industriell tankevärld och produktionsapparat. Och det tog knappast slut när vi nyligen passerade 20-procentsgränsen på väg nedåt. Tvärtom kan man hävda, att industrialiseringen fortsätter i den meningen att ett industriellt och ekonomistiskt tänkande genomsyrar alltfler samhällsområden i den västvärld vi tillhör. I resten av världen är industrisamhället på rask frammarsch, stödd av en ekonomisk och kulturell kolonialism som arbetar via världsbank och andra organ.

Att de sysselsatta i industrin har minskat sedan mitten av 1960-talet hänger bl.a. samman med kunskapsverksamheter brutits ut ur industriföretagen och blivit egna enheter med annan statistisk hemmahörighet. En stor del av tjänstesektorn arbetar också direkt åt industrin. En likaså stor del av statlig forskning och högre utbildning försörjer industrin med kunskap och kompetent personal osv. I den meningen består industrisamhället. Men man kan också fokusera på att omkring en tredjedel av arbetskraften redan arbetar $\mathrm{i}$ informa- tions- och kunskapsyrken. Om det inte ensamt räcker som belägg, innebär det dock, att det finns en bred folklig erfarenhet av det nya som i sig är en viktig förutsättning för allt tal om ett epokskifte.

En annan indikation är att ett eventuellt kunskapssamhälle redan har haft en lång mognadstid. Det är i viss mening samtida med industrisamhället. Båda har sina rötter i upplysningstidens rationalism och vetenskapens framväxt som källa för en ny sorts kunskap, skild både i tillkomst och art från erfarenheten och visdomen. Vägen till nuet kantas inte av ångmaskiner och elkraft utan av allmän folkskola, universitet, museer och hembygdsgårdar, så småningom 1900-talets vetenskapliga explosion och framväxten av IT. Men det behövs mer än så för ett mentalt epokskifte.

\section{MISSLYCKANDEN MOT FRAMTIDSLÖFTEN}

Vad detta «mer än så» är kan vi få ett hum om genom att återigen se på övergången från jordbruks- till industrisamhälle men från en annan vinkel. Den förbereddes och försiggick på åtminstone två skilda plan. På det ena handlade det om samhällets förmåga att fungera. På det andra om tolkningsföreträden och metaforer.

Mot slutet av 1800-talet blev det uppenbart, att jordbrukssamhället inte förmådde lösa tidens stora problem. Varken arbetstillgång eller matproduktion växte $\mathrm{i}$ takt med befolkningen. Trots utvandring och inre kolonisation i norr steg antalet verkligt fattiga. Folkhälsan hotades av epidemier och undernäring. De svåra nödåren gjorde misslyckandet grymt övertydligt.

I det läget framstod det nya och växan- 
de, som man ännu inte visste skulle bli ett industrisamhälle och vars potential man bara kunde ana, som ett lockande framtidslöfte. Det erbjöd inte bara hopp om jobb åt det stora landsbygdsproletariatet och nya bidrag till BNP. Nya investeringar blev möjliga. Exporten växte. Det var också inom detta nya samhälles rationalistiska tankevärld som man skapade motåtgärder mot den tidens miljöproblem, främst den katastrofala hygienen $\mathrm{i}$ de växande städerna. Jordbruket fick nya medel till förfogande som ökade skördarna och lindrade svälten osv. Raden av stora världsutställningar gjorde visionerna tydliga.

Man bör kunna betrakta den nu postulerade övergången till ett informationseller kunskapssamhälle på samma sätt. Efter ett århundrade av framgång på det materiella planet tycks industrisamhället vara på väg att misslyckas i väsentliga avseenden, åtminstone $\mathrm{i}$ vår del av världen. Visserligen förmår det att alltjämt bära upp en hög konsumtionsstandard i västvärlden. Men arbetslösheten ökar trots växande industriproduktion. Alltfler ställs utanför medverkan och tillhörighet. Missbruk och våld tilltar. Miljöproblemen hopas och resursbasen är långt ifrån så uthållig som man velat tro. Hela västvärldens samhällsbygge tycks vackla.

Om misslyckandet som den ena komponenten i ett epokskifte tornar upp sig som en hotfull möjlighet, återstår ändå frågan om framtidslöftena. På sådana råder ingen brist. Vi serveras dagligen rosiga förhoppningar om en bättre framtid i kunskapssamhället och med IT till hjälp. De flesta av dessa framtider ligger dock i industrisamhällets raka förlängning. Kunskapsmassan är större och tekniken mer raffinerad. Men hoten mot samhällets fortbe- stånd tycks ändock förbli ungefär desamma.

Det kan därför inte uteslutas att det mer är fråga om verklighetsflykt än om reella förändringar. Cullheden (1995) menar att «drömmen om att förvandlas» hör till vår kulturs livsnerv. «Vår kultur färgas av längtan att bli en annan, av hoppet om att födas på nytt». Det finns därför anledning nalkas föreställningarna om en ny samhällsform med åtskillig och nykter skepsis. Frågor om makt och vanmakt, om vinnare och förlorare kommer då $\mathrm{i}$ intressets centrum.

\section{TOLKNINGSFÖRETRÄDEN OCH METAFORER}

På maktplanet skedde övergången från jordbruks- till industrisamhälle stegvis. Via franska revolutionen och dess efterföljare bröt en ny borgarklass den jordägande feodaladelns dominans. I folkdjupet skedde en motsvarande maktförskjutning senare, när industriarbetarna, som följd av fabrikssystem och urbanisering, kunde organisera sig för att göra sina intressen gällande. Men det var först när den nya borgerliga eliten, industrialisterna och kapitalägarna, tillsammans med industriarbetarna erövrade ett kulturellt tolkningsföreträde som hela utvecklingen mer allmänt kom att uppfattas som en övergång från en samhällsform till en annan. Metaforen industrisamhället blev vedertagen.

Det hindrade inte att de materiella anledningarna till konflikter fanns kvar. Marx' analyser av det kapitalistiska industrisamhället spelade stor roll. Kamp mellan socialister och kapitalister kom länge att dominera den politiska dagordningen. Men ur den gemensamma synen på sam- 
hällets nya karaktär växte så småningom också ett samförstånd mellan samhällspyramidens topp och bas, som inte bara lade en grund för ekonomisk framgång utan också kom att innesluta i stort sett hela nationen. Välfärdssamhället blev det moderna industrisamhällets ljusa framsida.

Vem och vilka har då intresse $\mathrm{i}$ att än en gång växla metafor. Tengström (1987) väljer titeln, «Myten om informationssamhället» när han ger sig in på temat. Begreppet myt betyder här varken djupliggande insikt, som i kulturhistoria eller en smula lögnaktig beskrivning, som i vardagsspråket. I den ekonomiska teori- och begreppsvärld han lutar sig mot är myten en föreställning, en framtidsbild som någon viss grupp odlar och torgför som grund för en strategi att främja egna intressen.

Därmed ger titeln förväntningarna på en djupgåeende diskussion i ett maktperspektiv. Tengström nämner också den omfattande litteraturen i ämnet och exemplifierar med Gouldner (1977). Han tvivlar heller inte på att informationsteknologin kommer att växa in i samhället. Men på det hela taget tonar han ner maktfrågan och klasskampsperspektivet på ett sätt som kanske var motiverat i 80-talets ännu ganska sammanhållna Sverige.

I vårt 90-tal, med en arbetslöshet på 30talsnivå, med pigdebatt och snabbt stigande löner för en kunskapshanterande elit och där folkhemmets död tas för ett givet faktum ter sig saken dramatiskt annorlunda. Lanserandet av informations- och/eller kunskapssamhället som vägledande metafor för framtiden är också så mycket tydligare. IT marknadsförs både kommersiellt och av statliga organ med en kraft som saknar motsvarighet $\mathrm{i}$ vår erfarenhet. Veten- skapens verkstäder hyllas, som aldrig förr, som källa till all viktig kunskap osv.

Många menar att det som sker bestäms av omvärlden och den tekniska utvecklingen och därför är objektivt nödvändigt. Men det är också uppenbart, att om kunskapshanterarna är ute efter att etablera sig som den nya «klassen» genom att sälja in en framtidsbild i vilken de själva har huvudrollen, så utgör just hävdandet att skeendet är objektivt nödvändigt en självklar del i strategin. Vad diskussionen gäller är därför inte att mer information och växande kunskap är viktiga komponenter $\mathrm{i}$ det framtida samhället. Om det är vi nog alla ense. Den gäller om detta förhållande skall tas till intäkt också för att läsa in en djupgående förändring av samhällets hela art i det som sker och låta den, i sin tur, motivera att makt och förmåner fördelas om i hela samhället.

\section{ÖVERBLICK ELLER FRAGMENTERING}

Kunskapssamhället lovar, på propagandaplanet, inte bara ekonomisk tillväxt i 90talets ekonomistiska perspektiv och effektivare lösningar på vardagens problem utan även att öka vår kunskap och därmed vår förmåga att hantera de stora hoten krigen, miljöförstöringen, fattigdomen. Vad vi får ur vetenskapens verkstäder är emellertid en alltmer specialiserad och fragmenterad kunskap. Att vi ur IT-verkstäderna samtidigt får en formidabel kapacitet att lagra och plocka fram dessa kunskapsbitar när vi behöver dem, löser inte de problem detta överflöd för med sig.

Den stora risken är att mängden kommer att helt överflygla möjligheterna till överblick och meningsfylld användning. 
Folk i gemen kan komma att drunkna i eller åtminstone simma helt vilse $\mathrm{i}$ informationsfloden. IT-teknologins möjligheter räcker inte för navigerandet. Meningsfull användning av kunskaper förutsätter också modeller och strukturer som binder samman urval av kunskapsfragment till helhetliga och begripliga bilder.

Det blir tillgången till denna senare förmåga som avgör vem som kommer att vara «modellstark eller modellsvag», vara "planläggare eller planlagd», ha "makt över metaforerna» eller hur man nu vill uttrycka saken.

Här ligger en stor frestelse för en ny kunskapselit att utöva makt. För det behöver den inte de primitiva redskap som politiska förtryckarregimer använt. Det räcker med att monopolisera modellerna och strukturerna. Det går att göra diskret med den språkliga sofistikering, som är ett av vetenskapandets vardagsverktyg. Bakom en mur av obegriplighet kan hela systemvärlden bli otillgänglig för andra än eliten. För en forskarvärld, som ju redan innehåller så mycket av tendenser att i sin egen "märkvärdisering» bli översåtlig, kan inte dessa frestelser vara främmande.

Som samhälleliga institutioner bör det vara museernas uppgift att bidra till att göra helheterna tillgängliga och fattbara för folk i gemen. Det är en uppgift som hittills har klarats med den humanistiska utbildning museifolk i allmänhet har. Det är långt ifrån givet att den kommer att räcka till att hantera störtfloden av ny kunskap och till att förstå de nya systemsamband som nu börjar iakttas och konstrueras vid vetenskapernas frontlinjer. Nya kompetenser kan därför komma att behövas. Möjligheten att det i stället blir traditionen av specialisering och autentici- tet i detaljerna som tar överhanden kan inte uteslutas.

\section{KONKRET MOT ABSTRAKT}

I cyberspace finns inga fysiska realiteter. Allt är modeller och abstraktioner av verkligheten eller av framtida önskade eller oönskade tillstånd. I vetenskapens värld håller modellerandet i datorerna på att ersätta de mödosamma laboratorieproven. 1995 ger oss ett aktuellt exempel. Frankrike motiverar sina kärnvapenprov med att det fattas några empiriska kunskapsbitar för att man skall kunna arbeta med modellering i stället för faktiska försök. Sedan man väl har bitarna, är man beredd att skriva på ett avtal om provstopp. Innebörden är emellertid, att man då kan utveckla sina kärnvapen vidare i cyberspace. Därmed blir provstoppet meningslöst, åtminstone som sätt att begränsa utvecklandet av kärnvapnen.

För en bred allmänhet blir utvecklingsverksamheten osynlig. Om några hackers kan bryta sig in för att se vad som pågår $\mathrm{i}$ de nya abstrakta vapensmedjorna, kommer det ändå inte att kunna tända opinioner så som fysiska sprängningar $\mathrm{i}$ en söderhavsidyll kunnat göra det hösten 1995.

Detta dramatiska exempel har en mångfald av både mer vardagliga och mycket avancerade motsvarigheter. Modellering i något hörn av cyberspace i stället för prövande $\mathrm{i}$ verkligheten blir normal metod på allt fler områden. Enligt Lasch (1995) finns i detta en risk att kreativt arbete alltmer kommer att betraktas som något som försiggår i datoriserade modeller av verkligheten, $\mathrm{i}$ "hyperverkligheten» och avskiljt från den fysiska värld där vanligt folk vis- 
tas och utför lägre sorters arbete. Han går till och med så långt att han menar att den högutbildade eliten helt enkelt försöker bygga sig sin egen värld, där de inte längre bryr sig om att försöka påverka majoriteten med rationella argument. De vill hellre, säger han, skapa sig "parallella eller 'alternativa' institutioner där de inte längre behöver konfrontera de oupplysta överhuvudtaget.»

Mot denna dystra bild måste ställas de möjligheter modellerandet i cyberspace skapar att visualisera och konkretisera framtider. I arkitektur och samhällsplanering används möjligheterna redan nu. För museivärlden måste tekniken öppna spännande möjligheter att utveckla sig, både som minne och som berättare. Men även där tekniken som sådan ger så positiva möjligheter finns självfallet den maktaspekt Lasch pekar på ständigt närvarande.

Utvecklingen mot abstraktion kan också få andra konsekvenser. Vetenskaplig kunskap är vad som ibland kallas "påståendekunskap», till sin art skild från "färdighetskunskap» och "förtrogenhetskunskap» (tyst kunskap, erfarenhet). I arbetets värld liksom i vardagen är det normalt de senare sorternas kunskap som är betydelsefull. Kompetens är ett bättre och mer heltäckande begrepp. I kompetensen är kunskap av olika sorter en, men bara en faktor. Social kompetens, kulturell kompetens, sinnenas kompetens osv. är andra viktiga beståndsdelar i denna verklighetsnära blandning

Kunskapssamhället tonar ofta fram som ett samhälle av formellt utbildade. De breda kompetenser, som bara kan byggas upp med konkret livs- och yrkeserfarenhet, kan därför komma att undervärderas till förmån för den smala, djupa och abstrakta vetenskapliga påståendekunskapen.

Både när det gäller att balansera abstraktionerna i cyberspace och riskerna att kompetenser blir undervärderade bör museerna, med sin långa vana att belysa och berätta med fysiska föremål, att arbeta med livsberättelser, att tala till sinnena likväl som till intellektet, ha goda möjligheter att göra konstruktiva insatser.

\section{NATURENS ÄNDLIGHET, KUNSKAP OCH FUNDAMENTALISM}

Under medeltiden betraktades den fysiska världen och mängden resurser till människors förfogande som given. På samma sätt var samhällets hierarkiska ordning, i vilken alla hade sin rättmätiga plats, given av Gud. Sambandet var uppenbart. På samma sätt blev 1700-talets nya tro att världen kunde vidgas och resurserna förmeras med kunskap och uppfinningsrikedom en förutsättning för att också de av Gud givna hierarkierna slutligen kunde ifrågasättas. Ur detta växte det moderna samhället med tro på en oändlig tillväxt och ett nästan lika obegränsat utrymme för sociala uppfinningar och social rörlighet. (Liedman 1993).

I det sena 1900-talet har vi blivit varse att den fysiska världen här på jorden är ändlig och att de materiella resurserna $\mathrm{i}$ någon mening är givna. Hur mycket mer välstånd vi med ny kunskap, uppfinningsrikedom och kretslopp kan krama ur dem vet vi inte. Men att gränserna finns och att den resursbas på vilken vi byggt industrisamhället inte är uthållig, är ändå en för hela vår samhällsförståelse omvälvande insikt.

Om vi nu är på väg in i ett kunskaps- 
samhälle blir dess första uppgift därför inte att syssla med abstraktioner. Den blir högst konkret att skapa en ny och uthållig resursbas för sin framtida existens och ta i bruk en teknik som är anpassad till de nya ramvillkoren. Det är en enorm och exalterande utmaning. Den möjliga levnadsstandarden för en växande världsbefolkning är direkt beroende av hur världssamfundet lyckas lösa den.

I detta ligger också möjligheten att det framtida samhället kommer att förstås och sammanfattas $\mathrm{i}$ något helt annat begrepp än kunskapssamhälle. Att vi behöver mer kunskap för att hantera utmaningen är visserligen sant. Men den huvudsakliga effekten kan bli att det konkreta och biologiska upplever en renässans. Mängden fysiskt arbete kan tänkas öka i stället för minska. Lokala kompetenser kring naturgivna möjligheter kan visa sig lika viktiga som abstrakt och generell kunskap. Vart det bär är svårt att förutsäga.

Konsekvenserna kan också komma att nå djupare skikt än de som berörs av de direkta försörjningsfrågorna. Parallellt med att insikten om världens ändlighet bryter igenom, har religiös fundamentalism blivit en makt i världen, inte minst $\mathrm{i}$ USA. Förbud att undervisa om Darwins utvecklingslära diskuteras på fullt allvar. Följe slås med den mörkaste konservatism och dess tro på att samhällsordningen i stort sett är given och oföränderlig. Guds ordning håller på att på nytt upprättas.

Det reser den oroande frågan om man skall se ett kausalsamband i denna parallellitet. Är vi, för att ställa frågan annorlunda, på väg mot en modern variant av medeltiden, i vilken världens ekologiska ändlighet får motivera en ny av Gud given hierarkisk ordning, upprätthållen med den moderna ITns alla raffinerade hjälpmedel.

Risken för att en sådan dystopi kan bli verklighet ökar sannolikt, om vi inte kan klara av försörjningsproblemen $\mathrm{i}$ en allt folkrikare värld. Därmed är vi tillbaka till den stora utmaningen. I stället för att fly in $\mathrm{i}$ datormodellernas "hyperverklighet» kan forskarna och den intellektuella eliten i övrigt komma att behöva slåss högst konkret för den frihet de behöver för att alls kunna ta sig an utmaningen. Vad museerna kan göra åt saken behöver övervägas. Kanske är det just ändlighetens och gudsordningens historia de skall ägna sig åt för att hjälpa oss andra att tänka nya tankar kring vår egen tid.

\section{INTERNATIONALISM OCH TERRITORIUM}

Industrisamhällets relativa sociala samhörighet och solidaritet människor emellan har, som tidigare nämnts, hängt samman med banden mellan den ekonomiska oligarkin och industriarbetarna. Bofastheten har varit en viktig faktor i sammanhanget. I samlivet inom det egna territoriet har bryggor mellan skikten kunnat byggas och klasskillnaderna utjämnas.

$\mathrm{Nu}$ målar kunskapssamhällets förespråkare ständigt upp framtider med en ökad rörlighet $\mathrm{i}$ världen. IT ger möjligheter till samarbete i världsvida nätverk och de fysiska kommunikationerna gör personliga möten lätt tillgängliga. Varje studie visar ett ökat samarbete mellan svenska forskare och utländska kollegor. Kunskapseliten håller på att bli internationell. Det ökar forskningens effektivitet högst avsevärt, i synnerhet för ett litet land som Sverige.

Men fördelarna har också sitt pris. Kunskapseliten är inte bara på väg att lös- 
göra sig från det konkreta via cyberspace och datoriserade modeller utan också socialt och relationsmässigt genom att bygga nya gemenskaper internationellt. Klyftan till «de andra» växer på det sättet. Känslan av utvaldhet i det lokala, att tillhöra en annan grupp med andra privillegier kan antas växa av sådant.

Det skulle kanske inte vara så oroande om det enbart gällde kunskapshanterarna. Men samma fenomen kan iakttas för politiska och ekonomiska eliter. En kunskapselit kan knappast utmana de andra. Den uppenbara risken är en helt annan. Allianser mellan de tre eliterna kan komma att bli det maktens nätverk som med ITs hjälp behärskar ett framtida kunskapssamhälle. För de politiska eliterna, som nu sett sig utmanade och i viktiga avseenden överflyglade av de ekonomiska, måste det te sig frestande, även om demokratins kärna skulle ta skada.

Därmed skulle vi glida in i en utveckling som för tanken till den förindustriella tiden då adeln utgjorde ett internationellt härskarskikt. Banden tvärs över nationsgränserna mellan ståndsbröder och -systrar var starkare än mellan adelssläkten och folket. Man förde visserligen krig över nationsgränserna på ett sätt som förutsatte tillfälliga allianser med folket. Men minsta avbrott öppnade på nytt förbindelser och gränsöverskridanden. Och när den stora revolutionsepoken inleddes 1789 blev det tydligt, att sammanhållningen i det internationella toppskiktet alltjämt var starkare än den mellan nationell oligarki och folk.

Var finns då de möjliga motkrafterna? En inte ovanlig tanke är att de skulle kunna växa lokalt och regionalt om kunskapsarbetarna kommer att med stöd av IT bosätta sig utanför storstadsregioner och stora universitetsstäder och ta arbete och företagande med sig. I mindre städer och tätorter skulle något av det gamla industrisamhällets samverkan mellan grupper och skikt då kunna återuppstå. Internationella nätverk skulle bli socialt tillgängliga över hela landet. Lokala och regionala samhällen skulle förstärkas i stället för att försvagas. Och den vägen skulle demokratin kanske kunna vitaliseras och basorganisationerna lära sig, hur man håller toppskiktets elittendenser på mattan.

Vägvalet är inte givet. Som alltid förutsätter valen att alternativen är kända. Det förefaller som om historiska paralleller just i de här berörda avseendena skulle vara väl ägnade att belysa valmöjligheterna. Och vad kunde i så fall ligga bättre till för museer som vill bidra till framtidsdebatten.

\section{VÄLJA SIDA, NAGRA SAMMAN- FATTANDE REFLEXIONER}

Museernas uppgifter som kollektiva minnen och berättare om det förflutna påverkas rimligen av de samhällsförändringar som tentativt summeras i begreppet kunskapssamhälle. Att minneskapaciteter och resurser för försörjning med information växer dramatiskt i det omgivande samhället eller att hela cyberspace-tekniken ger museerna fascinerande nya arbetsinstrument kan inte lämna de inre arbetsmetoderna opåverkade. Det är en tämligen trivial observation.

Viktigare är att museerna också deltar i kampen om samhällstolkningar och problemformuleringsprivilegier, ibland kanske omedvetet, inte sällan bakom en fasad av akademisk vetenskaplighet. Någon gång sker det mycket medvetet. Hem- 
bygdsgårdarna skapades en gång som kampmedel i bondesamhällets motstånd mot det framträngande och hotande industrisamhället. Nordiska museet och Skansen kom delvis att användas i en liknande, om ock icke avsedd roll. Arbetets Museum är ett sentida exempel på medvetet ställningstagande med andra förtecken.

Om man ser föreställningen om kunskapssamhället som en myt (i den i det föregående angivna meningen) blir frågan om hur museerna skall förhålla sig viktig på ett nytt sätt. Som institutioner är de ju delar i systemet för informationsförsörjning och kunskapshantering. Personalen ingår i den stora grupp av kunskapshanterare som i ett kunskapssamhälle kommer att ha elitpositionen inom räckhåll. Egenintresset av att befordra föreställningen om ett kunskapssamhälle med privilegiernas mångfald tillfallande just kunskapsinstitutioner och professionella kunskapseliter kommer att vara betydande.

Det kräver en ny sorts vaksamhet, en ökad självinsikt, mer av öppen diskussion om den egna rollen och de egna förhållningssätten. Mot frestelsen att stärka myten i kunskapshanterarnas intresse måste ställas de samhälleliga behoven av att tillsammans med folk i gemen problematisera myten, att debattera och ifrågasätta den. Museerna måste välja sida.

Utgångspunkter, från vilka museernas speciella resurser kan ge väsentliga bidrag, saknas förvisso inte. Hur museerna väljer att använda dem, kommer att avgöra om de skall bli spännande och kämpande institutioner eller kulturella värmestugor för eliternas myter om samhällsutvecklingens nästa fas.

\section{LITTERATUR}

Cullhed Anders, Morgondagen väntar som ett oskrivet blad. DN 1995-10-12.

Eriksson Olof, Museerna och framtidsvisionerna. Ingår i Museiperspektiv, rapport från kulturraidet 1986:2.

Gouldner Alvin, The Future of the Intellectuals and the Rise of the New Class. 1977.

Lasch Christopher, Eliternas uppror och sveket mot demokratin. Svensk översättning. SNS Stockholm 1995.

Liedman Sven-Eric, Frain Platon till kommunismens fall. Stockholm 1993.

Tengström Emin, Myten om informationssambället ett humanistiskt inlägg $i$ sambällsdebatten.

Stockholm 1987.

\section{SUMMARY}

\section{Museums and the 'knowledge society'}

Everyone is aware that the amount of knowledge is increasing rapidly and it seems endlessly. Modern information technology, IT, provides the capacity for handling this knowledge and the means for world communication. More and more people are working with knowledge and information and so on.

The question that I raise is whether this development also gives us reason to talk about a major transition from an industrial to an information or knowledge society.

An additional, and more palpable time for positing a transition could be that the industrial society of the late 20th century is facing serious troubles unemployment, social instability, violence and more and more collisions with the limits of the global ecological space. The knowledge society as it is usually described offers us new patterns for work and everyday life. But that does not mean that it also guarantees an automatic solution to the problems mentioned above. 
OLOF ERIKSSON

12 On that account the whole concept seems to be much more of a tool for another kind of change. Behind the effort of marketing the knowledge society as the metaphor for a better future, can dimly be seen the forming of a new class of knowledge producers and handlers. A class striving for power, position and material benefit.

In addition the cream of this new class is developing into an international elite. It is not by chance that it will remain as the core of the international scientific society. Together with the corresponding economic and political elites that already exist, it could if the worst comes to the worst form a new and strong network of power at the very top of society. Ordinary people risk being left behind with a very limited influence on their own society.

Another set of risks is connected with the worship of specialized scientific knowledge. Other forms of knowledge as well as common experiences from life and work risk being downgraded in the shadow of the enormous piles of fragmented bits of knowledge that are produced by scientific institutions. Irreparable damage to competence in industrial life, public administrations and society as a whole may easily be the result.

The museums themselves are a part of the knowledge and information structure. Thus every museum and its staff must make a choice: either to join the new class and its struggle for power, position and benefits, or to try to develop the museum into a marketplace for public and critical debate. A debate on the risks and possibilities connected with what might possibly, but far from certainly, turn out to be a turning point in history.

Olof Eriksson är arkitekt och professor. Han har varit verksam vid den statliga byggnadsstyrelsen, cheffor statens råd for byggnadsforskning, chef for sekretariatet for framtidsstudier, arbetat vid expertgruppen for forskning om regional utveckling, ERU, och är nu bl.a. ordforrande for Dalarnas Forskningsråd. Adr: Tornedalsgatan 27, S-162 21 Vällingby. 